\title{
THE INSTITUTIONALIST REACTION TO KEYNESIAN ECONOMICS
}

\author{
BY \\ MALCOLM RUTHERFORD AND \\ C. TYLER DESROCHES
}

\section{INTRODUCTION}

It is a common argument that one of the factors contributing to the decline of institutionalism as a movement within American economics was the arrival of Keynesian ideas and policies. In the past, this was frequently presented as a matter of Keynesian economics being "welcomed with open arms by a younger generation of American economists desperate to understand the Great Depression, an event which inherited wisdom was utterly unable to explain, and for which it was equally unable to prescribe a cure" (Laidler 1999, p. 211). ${ }^{1}$ As work by William Barber (1985) and David Laidler (1999) has made clear, there is something very wrong with this story. In the 1920s there was, as Laidler puts it, "a vigorous, diverse, and distinctly American literature dealing with monetary economics and the business cycle," a literature that had a central concern with the operation of the monetary system, gave great attention to the accelerator relationship, and contained "widespread faith in the stabilizing powers of counter-cyclical public-works expenditures" (Laidler 1999, pp. 211-12). Contributions by institutionalists such as Wesley C. Mitchell, J. M. Clark, and others were an important part of this literature.

The experience of the Great Depression led some institutionalists to place a greater emphasis on expenditure policies. As early as 1933, Mordecai Ezekiel was estimating that about twelve million people out of the forty million previously employed in the

\footnotetext{
University of Victoria and Erasmus University. The research for this paper made use of the Wesley Mitchell papers, the J. M. Clark papers, and the Oral History Research Office Collection, Butler Library, Columbia University, the Alvin Hansen papers at the Harvard University Archives, the E. E. Witte papers at the Wisconsin Historical Society, the Mordecai Ezekiel papers at the Franklin D. Roosevelt Library, the Archive of the USDA Graduate School at the National Agricultural Library, and the Rockefeller Foundation Archives at the Rockefeller Archive Center. Thanks to David Laidler, Don Moggridge, Bob Dimand, John Davis, Fred Lee, and two referees for helpful comments. The research for this paper was made possible by a research grant from the Social Science and Humanities Research Council of Canada. ${ }^{1}$ Examples of this line of argument can be found in Myrdal (1972, pp. 6-7) and Ross (1991, p. 419). The same line of argument is repeated most recently by Hodgson (2004, p. 384). Ross argues "Institutionalism as a movement ... fell victim to the Great Depression and its Keynesian remedy. For self proclaimed experts in historical change, their inability to come to any better understanding of the Depression than their neoclassical colleagues was a considerable deficit."
} 
"industrial sector" were unemployed and that unemployment relief, to be effective, "must start with a large scale and vigorous program of construction and public works" (Ezekiel Papers Box 1, Folder: Agriculture, US Dept of 1932-33). From the early 1930s J. M. Clark was working on his own version of the multiplier, ${ }^{2}$ and published on the cumulative effects of changes in aggregate spending in 1935 in research conducted for the National Planning Board (Clark 1935a, 1935b). Others within the New Deal administration, particularly Laughlin Currie, were also developing and promoting a consistent program of Government expenditures from 1935 onward. Currie's ideas found support from institutionalists such as Ezekiel and Isador Lubin. The Keynesian Revolution in America, then, had many of its roots in the work of New Deal economists, both institutionalist and otherwise (Barber 1996, Laidler 1999).

It is also worth mentioning the institutionalist background of the person who became the leading American Keynesian, Alvin Hansen. Hansen completed his Ph.D. dissertation "Cycles of Prosperity and Depression, 1902-1908" in 1918 at Wisconsin, his supervisors including R. T. Ely and J. R. Commons. ${ }^{3}$ Although Hansen did not associate himself with the institutionalist movement, and initially developed more of an interest in European cycle theories, ${ }^{4}$ he maintained a close concern with the problems of unemployment, unemployment compensation, social security, and held to a social reform program with obvious Wisconsin roots. When Hansen took to Keynesian economics he married a Keynesian "full employment program" with a "comprehensive system of social security," adequate public education including adult education and research, adequate public health facilities and services, adequate provision of housing including public housing, urban redevelopment and renewal, river valley development along the lines of the TVA, conservation of agricultural and forest resources, and improvement of transportation facilities ("A Full Employment Program," Hansen Papers, 3.42, Research Notes, Box 2).

The relationship between institutionalism and what became Keynesian economics is, however, a complex one. Parts of what was institutionalism were taken over into the American Keynesianism of the 1940s, and there were certainly aspects of that Keynesianism that institutionalists could and did approve of. This however, should not be taken to mean that institutionalists simply adopted Keynesian ideas wholesale, because they most certainly did not. Hodgson's recent statement that "institutionalists such as

\footnotetext{
${ }^{2}$ There has been some debate over how fully Clark had developed his thinking on the multiplier prior to seeing Kahn's famous 1931 paper. For this debate see Fiorito (2001) and Dimand (2002).

${ }^{3}$ Hansen retained a great respect for Commons as can be seen in his speech "The Contributions of Professor John R. Commons to American Economics" given on the occasion of Commons's 70th birthday (Hansen Papers, 3.42, Research Notes, Box 1).

${ }^{4}$ There is a nice letter from Mitchell to Hansen concerning his work on cycles dating from 1924. Mitchell states that:

in view of the very large amount of purely empirical investigation that is now being done I think you are setting a good example in making use of general economic theory in your cycle studies. We ought gradually to get to a point where economists will turn from analytic to statistical work and back again in economics as habitually as physicists turn from mathematical to experimental work and back again (Mitchell to Hansen, March 19, 1924, Hansen Papers, 3.10, Box 2, Folder M).

For discussion of Hansen's career see Barber (1987) and Mehrling (1997).
} 
Mitchell, Commons, Clark, Copeland, and Ayres were very sympathetic to Keynes's theories and policies" (Hodgson 2004, p. 385) represents a significant overstatement. What will be argued below is that the institutionalist response to Keynes was a varied one, ${ }^{5}$ and involved some substantial criticisms of Keynesian economics on methodological, theoretical, and empirical grounds. These lines of criticism grew out of the several institutionalist research agendas on business cycles and unemployment that were active in the 1930s. Keynesianism did not simply arrive and sweep the board, but met challenges and criticism, and not just from more orthodox economists, ${ }^{6}$ but also from the more empirical and reform-minded institutionalist contingent.

\section{INSTITUTIONALIST RESEARCH AGENDAS OF THE 1930s}

Within institutionalist research on depressions and unemployment in the 1930s, there are a number of strands visible. The first of these is the program of empirical research on business cycles conducted primarily by Wesley Mitchell, Arthur Burns, and others such as Simon Kuznets and F. C. Mills at the National Bureau of Economic Research. This research built on Mitchell's earlier studies of business cycles (Mitchell 1913, 1927). In broad terms Mitchell saw business cycles as involving the functioning of an advanced "money economy" and deriving from the interaction of business decision making based on profit expectations, the banking and financial system, and the leads and lags in the adjustment of prices and wages. ${ }^{7}$ Mitchell also thought of the business cycle as a complex multi-causal phenomenon, and even with certain lines of causation changing over the course of the cycle. Mitchell was certainly familiar with Keynes's work and the work of other monetary theorists such as Cassel and Wicksell, and saw Keynes's Treatise on Money as a work that sought to make money a "larger element in general economics," and in that sense marking an important advance over the "real exchange" focus of earlier economists (Mitchell 1969, vol. 2, p. 826), but these developments in theory did not deflect Mitchell from his own empirical approach.

By the later 1930s the business cycle project at the NBER had expanded to include a vast array of studies of national income and its composition, cycles in particular industries and lines of activity, the structure of prices over the cycle, inventories over the cycle, employment and incomes over the cycle, cycles in stock prices, bond

\footnotetext{
${ }^{5}$ As will be seen below, this variation can be attributed to the different institutionalist lines of research that were operating in the 1930s, to some differences in methodological viewpoint, and to the degree of involvement with the policy making process within the New Deal Administration. The two main strands of institutionalist work on cycles and depressions were those based on the idea of business profit seeking combined with the working of the credit and price system, and those based on underconsumptionist ideas. Both strands can be found in Veblen (1904, pp. 177-267). Institutionalism was never a single research program, but institutionalists did share a number of broad methodological, philosophical, and theoretical commitments that serve to identify them and which informed their research programs. For a discussion of this and for an overview of interwar institutionalism see Rutherford (2003b, 2004).

${ }^{6}$ These more orthodox critics included Frank Knight, Henry Simons, Jacob Viner, Joseph Schumpeter, A. C. Pigou, Denis Robertson, Ralph Hawtrey, and Alvin Hansen (until his conversion to Keynesian ideas). See Laidler (1999, pp. 277-95). Criticism also came from F. A. Hayek, of course.

${ }^{7}$ Mitchell's emphasis on the role of pecuniary institutions and profit seeking in business cycles is taken from Veblen's discussion of cycles (Veblen 1904, pp. 177-212).
} 
yields, and much more. ${ }^{8}$ Out of this developed the "NBER method" of specific and reference cycles. The NBER approach was not to work with highly aggregated data, and their investigations discovered a considerable amount of variation between cycles, leading to a great deal of caution in the making of generalizations or in assuming the stability of certain relationships. All of this empirical work was intended to lead to a final theoretical volume to be called The Rhythm of Business Activity, but this volume was never produced. In terms of policy, Mitchell saw the empirical work of the NBER as linked to improved decision-making in both the private and public sectors, and holding out the prospect of stabilization via improved forecasting, indicative national planning, and counter-cyclical public works programs (Laidler 1999, pp. 221-22; see also Alchon 1985, pp. 71-90).

One aspect of this research program deserves special emphasis in the present context: F. C. Mills's work on prices, begun in the 1920s $(1927,1929)$ and continued into the 1930s. Mills's research found growing productivity in manufacturing industry over the 1920 s combined with large increases in profits and increasing price inflexibility. In his 1936 book he explicitly linked this price inflexibility to problems in "the wide and prompt diffusion of purchasing power" (Mills 1936, p. 440). Of course, Mills was not the only person concerned with the relative inflexibility of industrial prices; Gardiner Means published his first work on the subject in 1935, and continued throughout his career to stress the significance of administered pricing. During the Depression, farm prices had fallen much more than industrial prices, leading to a general concern with "price balance," but Mills's work linking productivity gains and price inflexibility to a rise in the share of profits was widely cited by other institutionalists and, as will be seen below, often used as part of an underconsumptionist argument.

A more theoretical strand of institutionalist work, although still relying heavily on the empirical work on business cycles done by the NBER, was that produced by J. M. Clark. Clark's Strategic Factors in Business Cycles (1934) was an attempt "to chart a course between the extremes of theoretical study which gave causes too far and too simple on the one hand, and inductive studies which revealed 'so many factors at work, so completely interrelated, that we are likely to come to the conclusion that everything is both cause and effect' and present too many complications to be of practical use" (Shute 1997, p. 92). The "short cycle" is described by Clark in terms that have their origin in Mitchell's 1913 volume, but with an emphasis on the accelerator mechanism, now expanded to include not merely capital goods but durable goods more generally. Clark also points to a number of other strategic factors including "movements of credit," and cyclical shifts in the proportionate distribution of income between different groups. These shifts, together with diverse habits of consumption and saving between the groups involved, lead to "instability in the proportions of the national income saved and consumed over the course of the cycle" (Clark 1934, p. 198). Findings such as those by Mills, Clark discussed in terms of longer term trends, with increased price inflexibility making the recovery process more difficult. At the same time, Clark was developing his version of the multiplier,

\footnotetext{
${ }^{8}$ A letter from Burns to Mitchell dated 1938 lists some thirteen monographs either under way or planned which were to form the background for Mitchell's planned final theoretical volume. Burns then goes on to suggest many additional pieces of research that may be required (Burns to Mitchell, December 12, 1938, Wesley Mitchell Papers, 1988 Addition, Box 46, Folder B).
} 
and his Economics of Planning Public Works (1935b) is an extended examination of the promise and problems of public works programs as a means of countering depression and unemployment.

Clark certainly favored a public works program to help the recovery, but in Clark's view the exact effects of any such program would also depend on the method of financing, what is happening to public expenditures more generally, and on the effect on private capital formation. Clark expressed himself in favor of public deficit spending for purposes of stimulating private sector investment, but he explicitly warned against the dangers of "unlimited" deficit spending, particularly its likelihood to crowd out private investment or have adverse effects on business confidence by creating a fear of inflation: "A fair conclusion seems to be that public-deficit spending cannot bear the burden of lifting production from the level of a serious depression without going so far as to bring about ... deferring effects on private business" (Clark 1935a, p. 19; 1935b, pp. 110-12).

If public expenditures are so handled as to tend to bring about a condition in which the volume of production and employment will become dependent on a perpetual continuation of such expenditures, then it will defeat the end of revival as that is commonly conceived, and will tend to bring us that much nearer the point at which the task of producing goods and maintaining the livelihood of the population could not be successfully handled by private business as now constituted (Clark 1935b, p. 112).

It is important to understand that, in Clark's hands, neither the accelerator nor the multiplier concepts were ever applied in a mechanistic fashion, but always with caution, and a concern for the other factors that might play a role in determining the final outcome.

Somewhat similar views can be found in the work of other institutionalists such as Sumner Slichter. In 1932 Slichter strongly supported the public works programs and deficit spending suggested by Senator Wagner (Barber 1985, p. 225), a position he continued to maintain in later work dealing with the depression (Slichter 1934, 1937). Like Clark, Slichter saw such deficit spending on public works as being a part of a "market supporting program" designed to "lift business out of the depression" (Slichter 1934, p. 175). Nevertheless, he was concerned that deficits be neither too large (as that may create business uncertainly) nor continued too long (as that may produce a fear of inflation), and was also concerned about possible adverse effects on relative prices (Slichter 1934, pp. 179-82). Slichter also emphasized the possible stabilizing role of unemployment reserves, and the importance of maintaining industrial research so that new technologies and investment opportunities may be created to produce a revival in private investment (Slichter 1934, p. 183; 1937).

A different strand of institutionalist thinking took to an explicitly underconsumptionist position, derived either from the work of John A. Hobson or from W. T. Foster and W. Catchings, ${ }^{9}$ and often making significant reference to the work by F. C. Mills

\footnotetext{
${ }^{9}$ Mariner Eccles is often regarded as one of the pioneers of a Keynesian approach within the New Deal administration but his ideas were more in the nature of those of Foster and Catchings, and he probably never read Keynes. Eccles was first invited to visit Washington by Rexford Tugwell (Barber 1996, pp. 85-86). Underconsumptionist ideas were also strongly promoted by Paul Douglas (1935). In his earlier work he referenced Foster and Cathchings, but later he tended to refer more to Hobson (Laidler 1999, pp. 225-26). Veblen's discussion of chronic depression contains underconsumptionist elements (Veblen 1904, pp. 25754; see also Vining 1939), and he refers to Hobson. The underconsumptionism found in the institutionalist literature of the 1930s is focused very much on the distribution of income and is clearly Hobsonian in nature.
} 
mentioned above. Hobson's work had attracted considerable attention in the United States, and he taught at the Robert Brooking Graduate School (headed by Walton Hamilton) in the 1924/25 academic year. Students at Brookings, who included Mordecai Ezekiel and Isador Lubin, were given significant exposure to Hobson's ideas (Rutherford 1994, 2003a).

A good example of this line of institutionalist thinking can be found in the work of Rexford Tugwell, a member of Roosevelt's "Brains Trust." Tugwell's position grew out of what was originally a highly optimistic view of the possibilities opened by new technology, holding out the promise of improved living standards for all (Tugwell 1927). A problem in the realization of this promise was a tendency to oversaving on the part of corporations (Tugwell 1931, 1932, 1935). Tugwell made explicit use of Mills's empirical work, arguing that firms with high overheads tended to try to build up reserves, and so did not reduce prices as costs fell. The 1920s were thus seen as a period of technological change but with little reduction in selling prices, raising profits and corporate savings, and a failure to enhance consumer purchasing power in proportion to productive potential. Tugwell, along with Mordecai Ezekiel and Gardiner Means, formed a group supporting a "structural" or planning approach to the depression. The planners supported a joint program of recovery and reform and favored some type of direct government intervention in order to increase purchasing power, allocate investment, and establish minimum standards. Many of the planners were in the Department of Agriculture and their ideas were most clearly displayed in the policies of the Agricultural Adjustment Administration (Barber 1996, Hawley 1966). Despite their emphasis on planning, it should be remembered that a key ingredient of their programs was to enhance the stream of consumer purchasing power. ${ }^{10}$

Quite closely related in spirit was the series of books produced by the Brookings Institution by Edwin Nourse, Harold Moulton, ${ }^{11}$ and others between 1934 and 1935: America's Capacity to Produce (Nourse and Associates 1934), America's Capacity to Consume (Levin, Moulton, and Warburton 1934), The Formation of Capital (Moulton 1935a), and Income and Economic Progress (Mouton 1935b). Nourse has stated that J. A. Hobson was "the intellectual daddy of what we did at Brookings on the Price and Income Books" (Knapp 1979, pp. 470-71). The main thrust of this study was summarized by A. F. Burns in the following way:

The central argument of the work is simple. The chronic retardant of economic progress is our method of distributing incomes. As national income has risen

\footnotetext{
${ }^{10}$ It is, of course, true that for the "planners" enhancing consumer purchasing power was only one aspect of their broader program. For the "Keynesians" such as Currie, increasing expenditure was the program. For an excellent discussion of the work on consumption and its relation to institutionalism and the program of the "planners" during the New Deal, see Stapleford (2006).

${ }^{11}$ The inclusion of Moulton and Nourse as institutionalists might be controversial. Moulton was, however, very much a part of the group, along with Walton Hamilton and J. M. Clark, who organized the 1918 AEA conference session that introduced the "institutionalist approach" to the profession. In his early years at the Institute of Economics (later The Brookings Institution) he hired many people of institutionalist persuasion, such as Isador Lubin, and he recommended Walton Hamilton to head up the Brookings Graduate School. Moulton and Hamilton fell out over the closing of the Brookings Graduate School in 1928 (Rutherford 2003a). It must be said that Moulton did come to adopt more conservative policy positions than most institutionalists. Nourse was a self-described institutionalist (Knapp 1979, p. 469), and became the first Chairman of the Council of Economic Advisors.
} 
expenditures on consumption goods have failed to keep pace....The proper remedy for our economic difficulties is to increase the purchasing power of the masses, and this may be best achieved by passing on to consumers the benefits of technical progress thru price reductions (Burns 1936, p. 477).

The first volume of the series, America's Capacity to Produce, was an attempt by Nourse to estimate the productive capacity of the United States between 1900-1930. Nourse estimated a capacity to produce significantly in excess of actual production but found no evidence of a build-up of excess capacity immediately prior to the depression. $^{12}$ The second volume of the series, America's Capacity to Consume, was written primarily by Moulton, and sought to assemble "a number of estimates relating to the volume of national income, its distribution by size among families, and the relation between income and savings" (Kuznets 1936, p. 301). Moulton's study argued that consumption had not kept up with potential output due largely to a growing inequality in its distribution. Too much was going into savings rather than consumption. The third volume dealt with capital formation, and presented capital formation as depending on consumer expenditure rather than on the volume of saving. Excess savings, had, according to Moulton gone into the bidding up of stock prices and other asset values. The final volume, Income and Economic Progress, included a summary and a discussion of policy:

Our study of the productive process led us to a negative conclusion-no limiting factor or serious impediment to a full utilization of our productive capacity could there be discovered. Our investigation of the distribution of income, on the other hand, revealed a maladjustment of basic significance. Our capacity to produce consumer goods has been chronically in excess of the amount which consumers are able, or willing, to take off the markets; and this situation is attributable to the increasing proportion of the total income which is diverted to savings channels. The result is a chronic inability ... to find market outlets adequate to absorb our full productive capacity (Moulton 1935b, p. 16).

Moulton's solution to this problem ran in terms of a "price policy" to ensure that productivity advances were passed on to the mass of consumers through declining prices, but no real mechanism for doing this was suggested other than one of persuading large corporations to adopt a low price policy. ${ }^{13}$ As a part of this, Moulton argued that his price policy would not reduce profits as firms could achieve lower costs with increased output. Moulton did consider other possible solutions, including redistribution of income, and public expenditures, but found them too limited in effect. He was in favor of public works programs to counter the depression, but was

\footnotetext{
${ }^{12}$ The idea that the economy might be characterized as having a chronic tendency to excess capacity is a theme that can be found in Veblen (1921) and in the work of others such as Stuart Chase's The Tragedy of Waste (1925). This was also a major motivating theme for the Report of the Columbia University Commission, Economic Reconstruction (1934), although many contributors, such as J. M. Clark, placed more stress on the problem of stabilization and control of fluctuations.

${ }^{13}$ The Moulton/Nourse policy suggestions were therefore quite corporatist in nature. Other such as Ezekiel sought more statist solutions involving some form of planning. On Mouton and Brookings, see Lee (1997). For a discussion of types of "planning" in America between 1930 and 1950 see Balisciano (1998).
} 
clearly not in favor of continued deficit financing of public expenditure. Government is not a "Santa Claus" and accumulated indebtedness ultimately involves higher taxes or a breakdown of government credit (Moulton 1935b, pp. 99-100).

The Brookings studies were widely discussed among institutionalists, and the first two books of the series had a particular impact. On one side, the Brookings studies elicited critical responses both from Arthur Burns and Simon Kuznets of the NBER. Kuznets complained that Moulton's analysis of capital formation was one sided, his empirical evidence sketchy, and his policy conclusions arbitrary and inconsistent (Kuznets 1936). Burns produced a very lengthy and detailed critique of the methods used, statistics produced, and inferences made (Burns 1936). Burns expressed much skepticism concerning the Brooking diagnosis of the problem as one of chronic oversaving, although he conceded a lack of adequate research on consumption and saving to that date. He also expressed bewilderment that the policy proposal did not seem to follow from the diagnosis. If maldistribution of income and oversaving are the problem then redistribution would be the solution, not a price policy that it is claimed will benefit all consumers and profit-makers alike.

On the other side, more positive responses came from some of those involved in the National Resources Board (later the National Resources Committee/NRC). Several commentators on the work on production and consumption undertaken by the Industrial Committee of the NRC have pointed to the impact of the Brookings studies Capacity to Produce and Capacity to Consume in providing a significant part of the inspiration for the Committee's work on industrial capacity and consumption patterns (Lee 1990, Stapleford 2006). Gardiner Means supervised extensive studies on industrial capacity and Hildegarde Kneeland supervised studies on consumption (including a large scale survey of family expenditure). This work culminated in Means's The Structure of the American Economy (1939), which he saw as a step towards developing a system interindustry planning (Lee 1990, Lee and Samuels 1992). More directly, Mordecai Ezekiel used the Brookings studies on production and consumption (as well as points from Gardiner Means) in his books \$2,500 A Year (1936) and Jobs For All (1939a), which contained versions of his "Industrial Expansion Plan," modeled on aspects of the AAA. ${ }^{14}$ This plan was designed to produce a coordinated increase in output and final demand, and raise real incomes. Ezekiel wrote that these books represented an attempt to provide a mechanism to carry "into action the general economic recommendations which Dr. Moulton had proposed in his book Income and Economic Progress" (Ezekiel to Leverett Lyon, January 11, 1939, Ezekiel Papers, Box 11; Ezekiel 1936, pp. 272-76). In the hands of Means and Ezekiel, the problems pointed to in the Brookings studies indicated the need for some form of planning rather than a price policy to be adopted voluntarily by corporations.

\footnotetext{
${ }^{14}$ Ezekiel was an early econometrician as well as an institutionalist. He received his training in statistics from the USDA Graduate School and his institutionalism from his time at Hamilton's Brookings Graduate School. A combination of sophisticated statistics and institutional economics was to become a feature of the USDA Graduate School training through the New Deal years (the subject of a future paper). Ezekiel himself taught at the School (Archive of the USDA Graduate School, Box 1, National Agricultural Library).
} 


\section{INSTITUTIONALISTS AND KEYNESIAN ECONOMICS}

In 1935 the U.S. Supreme Court found aspects of the National Recovery Act (NRA) unconstitutional, and a year later made a similar finding with respect to certain provisions of the Agricultural Adjustment Act. Virtually no economists, including the planners, approved of the way the NRA had worked in practice. ${ }^{15}$ Those in favor of planning argued for a reformulated NRA, and Ezekiel continued to present versions of his Industrial Expansion Plan through to 1939, but over the next few years the New Deal effectively moved into a second phase based predominantly on expansionary fiscal policy and more vigorous antitrust enforcement. This move was also promoted by the experience of the recession of 1937, caused, it was thought, by a sharp reduction in government expenditures (Barber 1996, pp. 108-12), and the congruence of the continuing work of Laughlin Currie with the publication of Keynes's General Theory of Employment Interest and Money in 1936. Ezekiel has described his own transition to Keynesian ideas as follows:

Both Currie and we [Ezekiel and Louis Bean] were working with elements of what later become known as the Keynesian theory. But although Keynes' book had been published in 1936, I myself didn't really catch up with it and absorb it fully until about 1939 or 1940. So, we were groping in the same direction that Keynes was working in England. Currie, as a matter of fact, who was the financial economist, came the nearer of any American economist to preceding Keynes in the discovery of the effect of the possibility of under-employment equilibrium and the way in which government programs worked to offset it. Of course, at the beginning of the New Deal, it was felt that the pump could be primed by public works to get activity going and then, after awhile, that could be withdrawn and they would keep on going by themselves. But when they were withdrawn in 1936-1937, that led to a new recession. And that led to a[n] awareness that however pump-priming worked, it didn't work as a primer. Something had to be kept up if conditions were such as to call for it. Later, Keynes' analysis gave a very clear and eloquent exposition of just how it worked (Reminiscences of Mordecai Ezekiel 1957, on page 96 in the Columbia University Oral History Research Office Collection).

Also, sometime between 1936 and 1938, Alvin Hansen made his transition to a Keynesian position (Barber 1987). Hansen's version of Keynesianism connected the idea of unemployment equilibrium to a stagnationist (or "mature economy") thesis: that is, that insufficient investment opportunities were keeping investment below the level of full employment savings. The government would thus have to play a more permanent role in maintaining aggregate demand, and not merely act to "prime the pump" for private investment. Of course, the Keynesian program could also be connected to a policy of progressive taxation and redistribution through programs such as social security, designed to increase the buying power of the poor. This would reduce the need for deficit financing of public expenditures. This version of the

\footnotetext{
${ }^{15}$ None of the institutionalist planners were happy with the method of code making under the NRA, which rapidly became a way for trade associations to attempt to fix minimum prices. Walton Hamilton and Gardiner Means were involved in the attempt to better represent the consumer interest within the NRA. The AAA had a significantly better method of consumer representation. See Rutheford (2005b).
} 
Keynesian program was perhaps most evident in work by Currie, but Hansen also favored tax and social policies involving redistribution (Barber 1987).

The Currie-Hansen program had been pretty much worked out by 1940, and it did gain institutionalist adherents. Isador Lubin gave his support and, according to Barber, Ezekiel had fully transitioned to a similar position by 1941 (Barber 1996, p. 128). In the late 1930s and early 1940s Ezekiel did considerable amounts of empirical work on consumption, savings, and investment, with many references to America's Capacity to Consume, but with increasing reference to Keynes (Ezekiel 1937, 1942). This transition to Keynesian ideas can also be seen very nicely in Ezekiel's 1939 paper "Keynes versus Chamberlin" (Ezekiel 1939b), which presents a clearly Keynesian analysis of full employment saving exceeding investment, although with an added concern with monopolistic competition, and still with one reference to his Industrial Expansion Plan.

The larger history of the shift in view within the NRC from Means's structural planning to a Keynesian style fiscal policy has been told elsewhere (Lee 1990), but it is certainly the case that both Lubin and Ezekiel were a part of that shift. Leon Keyserling, a former student of Tugwell's who became closely associated with Senator Wagner and a leading proponent of the 1945 Full Employment Bill, also adopted a set of ideas very similar to Currie's that he combined with some of Tugwell's planning perspective. Keyserling would, however, downplay the specifically Keynesian contribution to his advocacy of public expenditure and redistribution, and it is noticeable that Keyserling complained that many Keynesians neglected the distributional aspects of Keynes teachings (Keyserling 1972). ${ }^{16}$ For Keyserling, the problem was the maldistribution of income and savings, and this maldistributionist and redistributive interpretation of Keynesian economics was also adopted by Clarence Ayres, who became an advocate of guaranteed minimum incomes (Ayres 1938, 1966). Thus, a number of younger institutionalists, and particularly those most closely involved with the policy discussions in Washington, did make a transition to Keynesian views, although the inspiration for this shift came as much or more from Currie than from Keynes himself.

More critical discussions of Keynes and Keynesian economics (particularly the Keynesianism of Alvin Hansen), however, came from J. M. Clark, Sumner Slichter, A. F. Burns, Edwin Nourse, Harold Moulton, and Morris Copeland. Gardiner Means also remained a critic of Keynesian analysis, continuing to emphasize the role of administered pricing and developing his own monetary theory of aggregate demand (Lee and Samuels 1992). ${ }^{17}$ Some relevant material can also be found in the debates over the funding of Social Security involving E. E. Witte, other Wisconsin institutionalists, and the "Keynesians." 18

\footnotetext{
${ }^{16}$ Keyserling was a member of the first Council of Economic Advisors and succeeded Edwin Nourse as Chairman. For a discussion of Keyserling, see Brazelton (1997).

${ }^{17}$ Means's work on administered prices led him to the view that the "appearance of an oversaving problem" was really product of price inflexibility. Attacking administered pricing in the sectors where it appeared most prevalent would, according to Means, stimulate investment (Means 1939; Barber 1996, p. 127).

${ }^{18}$ Commons does not say much about Keynes. In Institutional Economics (Commons 1934) he refers very occasionally to Keynes's monetary theory work. The General Theory is mentioned briefly in Commons's discussion of Mouton and the Brookings books. Commons presents Keynes as supporting a price stabilization policy rather than Mouton's price reduction policy, but says little about the Keynesian analysis of unemployment equilibrium or fiscal policy proposals (Commons 1937). Commons was always of the view that monetary policy should be conducted with a view to price stabilization.
} 
Within this institutionalist literature on Keynesian economics there are a number of common themes. There is a concern about dogmatism, about the too-mechanical use of simplified models, about the factors omitted from the model, about the empirical foundations of some key aspects of the model, about the thesis of "economic maturity," and the wisdom of continued deficit financing of government expenditure. Of those mentioned above, J. M. Clark was probably the most generously disposed towards Keynes and Keynesian economics, but even Clark expressed substantial reservations. Clark willingly conceded that "certain central problems cannot be successfully handled without the use (which does not imply exclusive reliance) of the income-flow method of analysis of which Keynes's studies are the most prominent form" (Clark 1942, p. 9). Yet in the next breath he states "Keynes offers a revised Ricardianism, of similar power and exposed to similar dangers, including that of undue dogmatism of the part of disciples" (Clark 1942, p. 9). A clear reference to the "Ricardian vice" of deriving policy recommendations from highly simplified models. Clark even wrote to Keynes using similar language:

It has seemed to me that what I call the "income-flow analysis", of which yours is the most noted presentation, has done something which has not been done in comparable degree since Ricardo and Marx: namely, constructed a coherent logical theoretical system or formula, having the quality of a mechanism, growing directly out of current conditions and problems which are of paramount importance and furnishing a key for working out definitive answers in terms of policy. On this a "school" has grown up. All that has tremendous power; and is also exposed to the dangers of too-indiscriminating application . . . I am myself enough of an "institutionalist" (whatever that may mean) to have more than a lurking distrust of formulas and equations! But not enough of an institutionalist to ignore their importance: merely to want to think all around them and reckon with the imponderables that modify their action; and the other factors which no single formula can comprehend-for instance, the long-run incidence of continued large deficit spending (Clark to Keynes, July 24, 1941, J. M. Clark Papers, Box 2). ${ }^{19}$

Clark also complained of the tendency of Keynesians to wish to intervene at any point short of "something called full employment," representing a position which may not be achievable through the policies advocated, their "obliviousness" to the importance of wage and price adjustments, their "philosophy of unlimited deficit spending as the one tested and reliable way to secure full employment," and their "dogma" that such spending will not tend to be dissipated in wage or price increases until full employment is achieved. These ideas, for Clark, were "unsupported by reason" and fly "in the face of experience" (Clark 1942, p. 9). In a letter to Hansen he argued that "indefinite deficit spending is not an enduringly workable solution for chronic partial stagnation of an economic system like our own" (Clark to Hansen, February 13, 1939, Hansen Papers, 3.10, Box 1).

Slichter also expressed concerns involving the possible inflationary effects of the Employment Act combined with the increased power of unions, and he strongly

\footnotetext{
${ }^{19}$ Keynes replied to this letter saying "I agree with what you say about the danger of a 'school', even when it is one's own" (Keynes 1941).
} 
rejected Hansen's stagnationist thesis, emphasizing instead the possibilities for private investment opened up by new technological advances (Slichter 1961, p. xiv; Leeson 1997, p. 447n). ${ }^{20}$

Mitchell and Burns had greater difficulties with Keynesian economics. Mitchell himself did not write on the General Theory, but he did discuss it in some of his seminars at Columbia. Keynes's work is presented as an attempt to integrate monetary theory and general economic theory, although largely within the "orthodox tradition" (Mitchell 1969, vol. 2, p. 826). Mitchell saw a need for such an integration, but also a need to "work on a deeper level than do Keynes and his disciples" (Mitchell 1969, vol. 2, p. 826). Mitchell's response to Keynesian enthusiasm on the part of students made it clear that he was not overly impressed (Interview with Eli Ginsberg, March 17, 2000). It was Arthur Burns who mounted the principal NBER criticism of Keynesian economics, although the correspondence from Burns to Mitchell concerning this critique makes it clear Burns thought he had Mitchell's general agreement with his position (Burns to Mitchell, December 18, 1936, Mitchell Papers, 1998 Addition, Box 46, Folder B). ${ }^{21}$

Some of Burns's language is strikingly similar to Clark's. He compares Keynes to Ricardo. Both had produced "bold and vigorous theoretical speculation" related to the pressing problem of the time, but both were subject to "serious error if the premises accepted for purposes of reasoning are contrary to fact" (Burns 1946, pp. $4,8)$. He was also concerned with the "religious" element he finds among Keynes's "more zealous followers." Although Burns admits that Keynes had an important liberating effect on those brought up within orthodox theory, "he failed to teach economists that economic truth cannot be firmly reached by speculation alone" (Burns 1947). For Burns, unless the economist examines the correspondence between speculation and actual facts, he "may be taking a grand vacation from life and its realities" (Burns to Joseph Willits, November 5, 1947, Rockefeller Foundation Archives, 1.1, 200S, Box 369, Folder 4371).

Burns also argues that Keynesians tend to assume that the consumption function is stable, that savings increase with income, and that private investment opportunities are too limited to assure full employment. Burns points out that equilibrium in a Keynesian model is at the aggregate level and does not imply that all markets or firms are in equilibrium, so that the final position may be not as predicted by the model. Furthermore, he points out that the research undertaken or being undertaken by the NBER suggests that the consumption function is far from stable, ${ }^{22}$ that the

\footnotetext{
${ }^{20}$ Slichter moved from a position in the 1940s that showed a great deal of concern with the possibility of inflation, to one in the 1950s and early '60s that strongly downplayed the significance of inflation (see Leeson 1997).

${ }^{21}$ Arthur Burns was more conservative than his mentor Wesley Mitchell, and much more Marshallian in his theory, but Mitchell's empiricism, concern with multiple causes, and variations between cycles, much influenced Burns. Burns succeeded Keyserling as Chairman of the Council of Economic Advisors.

${ }^{22}$ Simon Kuznets had already produced work concerning the longer run relationship between income and consumption (Kuznets 1942). Kuznets and Friedman's (Friedman 1945) work on income from professional practice also has significance here, particularly as the work had been completed many years before the final publication date. This work was followed by a series of studies at the NBER and through the Conference on Income and Wealth (Burns 1953) that were to culminate in the development of the permanent income hypothesis (Friedman 1957).
} 
secular trend of savings in relation to income has been downward, and that there is little clear evidence of secular stagnation as suggested by Hansen (Burns 1946). ${ }^{23}$ Burns also complained of Keynes's focus on the level of employment as opposed to the business cycle (Burns 1952, see also Wells 1994). Hansen replied to Burns, disputing the characterization of Keynesian economics as "Ricardian" in character, pointing to the empirical component in Keynesian macroeconomic work, and questioning Burns's understanding of Keynesian theory (Hansen 1947). Burns in turn wrote a lengthy rejoinder, backing down not at all:

I suspect that Hansen is troubled because my essay conveys the impression that the Keynesians are excessively mechanical in their thinking, that they gloss over the turbulent life that goes on within aggregates, that they give little heed to adjustment processes in our society, that they subject ceteris paribus to excessive strain, that they slight in particular the instability of the consumption function; and that while Keynes is guilty on all these counts, the Keynesians-among whom Hansen is outstandingare guiltier still (Burns 1947, p. 260). ${ }^{24}$

Morris Copeland also criticized Keynesian analysis, his most considered response coming in the early 1950s, after the language of "models" and "model building" had begun to find its way into the literature. Copeland admitted the popularity of the Keynesian model, and found the causes of this popularity in the facts that it was aggregative in nature, embedded in the neoclassical tradition, did not attempt to deal with the entrepreneur or consumer on an individual level, and lent itself to empirical investigation. This last point was one to which Copeland, as a statistical economist himself, attached considerable importance. It is also the case that Copeland's own work on unemployment and expenditure policy came to utilize Keynesian terms and ideas (Copeland 1944, 1966; Rutherford 2002). Nevertheless, Copeland complained about the number of factors omitted from Keynesian models, argued that the Keynesian contribution was one of "model analysis" alone, and that model analysis had serious limitations (Copeland 1951, 1952). Keynes's General Theory was too selective; "it omitted points that ought not to have been omitted" (Copeland 1952, p. 7). Being aggregative it omitted the detail of the cyclical process that had been such a central feature of the work of the NBER. Copeland argued the General Theory, in addition to ignoring relations with political and social theory, "added not to what we know about [macroeconomics] but our ability to express what we know in terms of model analysis" (Copeland 1951; 1952, p. 26).

Upholding the methods of institutionalism, Copeland aimed criticism at the limitations of model analysis, affirming it to be only a part of economic analysis. "Model analysis has thus far been confined to quantitative relationships and it has invariably involved a great oversimplification of the real world. Institutionalism has been concerned to emphasize the complexity of reality and the importance of

\footnotetext{
${ }^{23}$ A major critic of Hansen's stagnationist thesis was George Terborgh (1945). Terborgh had been a student at Walton Hamilton's Brookings Graduate School and had worked as an assistant to Laughlin Currie (Barber 1996, pp. 166-67).

${ }^{24}$ It is worth noting that this exchange with Hansen was occurring at the same time as the NBER came under attack from Tjalling Koopmans at Cowles for "Measurement without Theory" (Koopmans 1947, see also Rutherford 2005a).
} 
qualitative as well as quantitative facts" (Copeland 1951, p. 57). Not only was the General Theory limited to model analysis, for Copeland, Keynesian models were lacking key factors and details; they were an "expurgated" version of Mitchell's theory of business cycles. It is quite clear that Copeland felt that any such simplified model would have limited applicability and predictive capacity (Copeland 1951, 1952).

Nourse and Moulton had particular difficulties with Keynes and Hansen on the policy front. Moulton wrote in 1949 that "Keynes's analysis has little kinship with that of the Brookings Institution. It diverges sharply at critical points, and the ultimate implications with respect to the future of private enterprise are fundamentally at variance from ours" (Moulton 1949, p. 128). Neither Moulton nor Nourse appear to have been impressed by Keynes, and were suspicious of solutions to the depression that substituted government expenditure for private investment. Nourse held a highly skeptical view of the original 1945 Full Employment Bill, but was happy enough with the Employment Act of 1946 to accept the position of Chairman of the Council of Economic Advisors (Knapp 1979, p. 201). Nourse's concept of the role of the council and his reluctance to adopt the kinds of policies being advocated by Keyserling, however, led to his eventual resignation. Nourse continually expressed concern over the building up of government indebtedness, and criticized government for "slipping back into deficits as a way of life in a period when production and employment are high" (Knapp 1979, p. 327). He also doubted the effectiveness of marco level policy tools on their own: "even fiscal and monetary policy cannot be adequately analyzed and formulated in isolation from the processes of the private business world-collective wage bargaining, administrative price setting, capital formation and investment" (Knapp 1979, p. 405). Those who believed in the certain ability of monetary and fiscal policy alone to control the level of economic activity he called "a cult of economic magicians" (Knapp 1979, p. 405). He also very pointedly rejected Hansen's stagnationist views, and continued to promote a "price policy" (Nourse 1944).

Not surprisingly, Moulton held similar views of Keynesian economics. In Capital Expansion, Employment, and Economic Stability Moulton and his co-authors argue that the idea of the American economy having reached a mature state is false. They point out that "a primary implication of the conception of economic maturity is that government must increasingly supplant private enterprise" (Edwards, Moulton, Lewis, and Magee 1940, pp. 163-64). The authors reject the thesis and its implication. Moulton's The New Philosophy of Public Debt (1943) carries the argument on to a direct criticism of what Moulton took to be the disregard of the problem of government debt by Keynesians such as Hansen. Moulton draws a distinction between the traditional view and the new conception of public debt. He describes the former as the view that "a continuously unbalanced budget and rapidly rising public debt imperil the financial stability of the nation," and the latter as the idea that "a huge public debt is a national asset rather than a liability and that continuous deficit spending is essential to the economic prosperity of the nation" (Moulton 1943, p. 1). Moulton argues that those who adopt the new philosophy believe that "public finance is really only a matter of book keeping, that a rising debt has no adverse consequences, and that without a constantly increasing debt we cannot hope to have full employment and prosperity" (Moulton 1943, p. 3). Hansen's supporters responded with the charge that Moulton was misrepresenting Hansen's position 
(Wright 1943, 1945), a charge that drew angry denials from Moulton (Hansen Papers, 3.42, Box 7).

That many institutionalists took a much more cautious attitude towards government debt than those on the Keynesian side can also be seen clearly in the debates surrounding the financing of social security. The original Social Security Act of 1937 involved funding from payroll taxes only and included provision for a reserve fund and contemplated working towards a fully funded system of social security. The large Wisconsin contingent involved in Social Security, including Arthur Altmeyer and E. E. Witte, favored creating a full social security reserve fund (Witte 1937). Witte argued that failure to set up a full reserve would only result in higher taxes later on. He wrote, "if the money collected from these [younger] workers is not in some fashion set up to their credit, there is the grave danger that the entire scheme will become one for taxing the working people for old age assistance extended to aged dependents of the present day" (Witte to Theresa McMahon, October 7, 1937, Witte Papers Box 34). On the other side of this argument were the "Keynesians," including Currie, Eccles, Hansen, and Keyserling (Keyserling 1972), who favored a pay as you go policy financed by progressive taxation. Others involved in the debate over social security, such as Abraham Epstein and Paul Douglas (Epstein 1936, pp. 793-806; Douglas 1936), were also highly critical of Witte's position. The revisions to the Social Security system made in 1939 moved away from exclusive reliance on payroll taxes, and the role of the reserves was reduced to that of a contingency fund.

\section{CONCLUSION}

Institutionalists had a deep and abiding interest in the problems of unemployment and business cycles that ran back to the very beginnings of the movement immediately after World War I. They supported many types of intervention in the economic system under the rubric of "social control." They were not believers in the adequacy of unregulated markets to achieve the maximum of social welfare, and had often advocated for policies such as counter-cyclical public expenditures, and unemployment insurance plans. The experience of the Great Depression led to a number of lines of institutionalist research, a variety of policy proposals, and a good deal of debate even within institutionalist ranks.

But because they did have established research agendas themselves, their reaction to the "new" economics of Currie, Keynes, and Hansen was far from uniformly enthusiastic. Some institutionalists did take on such Keynesian ideas. Keyserling was an early convert, and he and Ezekiel and Lubin came to support the Currie-Hansen position on expenditure policy. Clarence Ayres also adopted Keynesian ideas. Sumner Slichter, too, became increasingly close to Hansen in his views after 1950, although even then he never accepted Hansen's stagnationist thesis (Leeson 1997). J. M. Clark began to use the language of income-expenditure models, despite his doubts about their adequacy, and even Arthur Burns could applaud the fact that Keynesian economics had made the profession at large recognize the problem of unemployment was "the principal problem in economic theory" (Burns 1946, p. 4).

Nevertheless, the leaders among the interwar generation of institutionalists remained skeptical about key elements of Keynesian economics. They did not like 
the degree of simplification in Keynesian models and were suspicious of the degree of aggregation and of the microeconomic detail left out. They were, in fact, highly doubtful about the entire "model building" approach to economics that was becoming dominant within the profession and displacing their own style of empirical economics. Their concerns, however, were not only methodological. The NBER business cycle program had shown a high degree of variation between cycles, and work on income and consumption was indicating that the Keynesian consumption function may not be as stable as assumed. They clearly did not accept Hansen's thesis of economic maturity with its implication of a need for ongoing government expenditure to make up for a lack of private investment. They were more concerned with reviving private investment than in finding a permanent substitute for it. Finally, most institutionalists were quite clearly more fiscally conservative than the Keynesians, and more concerned with maintaining price stability. They did not approve of ongoing government deficits, arguing that they would create inflation, damage business confidence, or impose long run burdens in the form of higher taxes.

In the context of the macroeconomic discussions in the immediate post World War II period, the policy concerns raised by the interwar generation of institutionalist critics of Keynesianism sometimes placed them on the more conservative side of the debate, warning of inflationary pressures and the need to consider microeconomic conditions. ${ }^{25}$ With the benefit of hindsight, and experience with Keynesian econometric models, government deficits, inflation, and social security funding problems, their concerns seem to have been more than justified.

It is true neither that criticism of Keynes came only from more orthodox economists, nor that most of the interwar generation of institutionalists adopted Keynesian ideas. What did happen was that many of the leading interwar institutionalists remained quite suspicious of several key aspects of Keynesianism, but Keynesian economics appealed to the type of younger economists who in the early 1920s might have joined the institutionalist ranks. What institutionalism had promised then was a new approach to economics, one that related to the pressing problems of the day, and one that appeared to offer effective instruments for the improvement of economic performance. That is exactly what Keynesian economics held out to those beginning their careers in the 1940s. Also, Keynesian economics, with the linkages that Hansen gave it to a broad array of social programs, took over and expanded the social reform agenda that had been so central to inter-war institutionalism. The institutionalist movement declined after World War II, partly because of this, and the research programs they had initiated were displaced first by Keynesian modeling and then by the monetarist/Keynesian debates. ${ }^{26}$

\footnotetext{
${ }^{25}$ See for example J. M. Clark's very cautious approach as outlined in his statement in the Report to the UN, National and International Measures for Full Employment (Clark, et al. 1949). Clark is suggesting that for many times and places the unemployment rate achievable via macro policy without creating inflation may be much higher than the usual definitions of full employment.

${ }^{26}$ Interestingly, Friedman's attacks on Keynesian economics had their foundations in his work for the NBER. Friedman's work on U.S. monetary history and his quantity theory interpretation, however, represented a break from earlier NBER attitudes which had generally been skeptical about the quantity theory relation, and had placed more emphasis on the operation of the banking system and quality of credit issues. Walter Stewart was an important source of institutionalist thinking on monetary issues and his views were more in line with the banking school.
} 
Those few institutionalists who did come to prominence in the post-World War II period generally adopted a Keynesian style of macroeconomics, stressing the use of fiscal policy to achieve full employment. Institutionalist markers continued to be visible, particularly in the advocacy of additional policy tools, including some form of planning or price controls. Perhaps the most obvious example of this is J. K. Galbraith, but the work of others, such as Allan Gruchy, fits the same mold. ${ }^{27}$ Nevertheless, it can hardly be maintained that there were identifiable institutionalist research programs dealing with macroeconomic issues in the same sense that they existed in the 1930s.

\section{REFERENCES}

Alchon, Guy. 1985. The Invisible Hand of Planning. Princeton, NJ: Princeton University Press. Ayres, Clarence. 1938. The Problem of Economic Order. New York: Farrar and Rinehart.

Ayres, Clarence. 1966. "Guaranteed Income: An Institutionalist View." In Robert Theobald, ed., The Guaranteed Income. New York: Doubleday, pp. 161-74.

Balisciano, Marcia. 1998. "Hope for America: American Notions of Economic Planning Between Pluralism and Neoclassicism, 1930-1950.” In Mary S. Morgan and Malcolm Rutherford, eds., From Interwar Pluralism to Postwar Neoclassicism, Annual Supplement to Volume 30, History of Political Economy. Durham NC: Duke University Press, pp. 153-78.

Barber, William J. 1985. From New Era to New Deal. New York: Cambridge University Press.

Barber, William J. 1987. "The Career of Alvin H. Hansen in the 1920s and 1930s: A Study in Intellectual Transformation." History of Political Economy 19 (Summer): 191-205.

Barber, William J. 1996. Designs within Disorder. New York: Cambridge University Press.

Brazelton, Robert. 1997. "The Economics of Leon Hirsch Keyserling." The Journal of Economic Perspectives 11 (Autumn): 189-97.

Burns, Arthur F. 1936. "The Brookings Inquiry into Income Distribution and Progress." Quarterly Journal of Economics 50 (May): 476-523.

Burns, Arthur F. 1946. Economic Research and the Keynesian thinking of Our Times, $26^{\text {th }}$ Annual Report, National Bureau of Economic Research. New York: NBER.

Burns, Arthur F. 1947. "Keynesian Economics Once Again." Review of Economics and Statistics 29 (November): 252-67.

Burns, Arthur F. 1952. "Hicks and the Real Cycle." Journal of Political Economy 60 (February): 1-24. Burns, Arthur F. 1953. The Instability of Consumer Spending, 32 ${ }^{\text {nd }}$ Annual Report, National Bureau of Economic Research. New York: NBER.

Chase, Stuart. 1925. The Tragedy of Waste. New York: Macmillan.

Clark, John M. 1934. Strategic Factors in Business Cycles. New York: NBER.

Clark, John M. 1935a. "Cumulative Effects of Aggregate Spending As Illustrated by Public Works." American Economic Review 25 (March): 14-20.

Clark, John M. 1935b. Economics of Planning Public Works. New York: Sentry Press.

Clark, John M. 1942. "The Theoretical Issues." American Economic Review 32 (March): 1-12.

Clark, J. M., et al. 1949. National and International Measures for Full Employment. Lake Success, NY: United Nations.

Commons, John R. 1934. Institutional Economics. New York: Macmillan.

Commons, John R. 1937. "Capacity to Produce, Capacity to Consume, Capacity to Pay Debts." American Economic Review 27 (December): 680-97.

\footnotetext{
${ }^{27}$ For Gruchy's discussion of the relationship between institutionalism and Keynesian economics, see Gruchy (1950). For Galbraith, see Galbraith (1952).
} 
Copeland, Morris A. 1944. "How Achieve Full and Stable Employment." American Economic Review 34 (March): 134-47.

Copeland, Morris A. 1951. "Institutional Economics and Model Analysis." American Economic Review 41 (May): 56-65.

Copeland, Morris A. 1952. The Keynesian Reformation: Three Lectures. Delhi: Delhi School of Economics.

Copeland, Morris A. 1966. Toward Full Employment in our Free Enterprise Economy. New York: Fordham University Press.

Dimand, Robert W. 2002. "John Maurice Clark's Contribution to the Genesis of the Multiplier Analysis: A Response to Luca Fiorito.” History of Economic Ideas 10 (1): 85-91.

Douglas, Paul. 1935. Controlling Depressions. New York: Norton.

Douglas, Paul. 1936. Social Security in the United States. New York: McGraw Hill.

Edwards, George W., Harold G. Moulton, Celona Lewis, and James D. Magee. 1940. Capital Expansion, Employment, and Economic Stability. Washington, DC: Brookings Institution.

Epstein, Abraham. 1936. Insecurity: A Challenge to America. New York: Random House.

Ezekiel, Mordecai. 1936. \$2,500 A Year. New York: Harcourt, Brace.

Ezekiel, Mordecai. 1937. "An Annual Estimate of Savings by Individuals." Review of Economic Statistics 19 (November): 178-91.

Ezekiel, Mordecai. 1939a. Jobs for All. New York: Alfred A. Knoff.

Ezekiel, Mordecai. 1939b. "Keynes versus Chamberlin," Report of the Fifth Annual Conference on Economics and Statistics. Colorado Springs: Cowles Commission for Research in Economics, pp. 54-57.

Ezekiel, Mordecai. 1942. "Statistical Investigations of Saving, Consumption, and Investment, Parts I and II.” American Economic Review 32 (March): 22-49, (June): 272-307.

Ezekiel, Mordecai. 1957. Reminiscences of Mordecai Ezekiel. Columbia University Oral History Research Office Collection.

Fiorito, Luca. 2001. "John Maurice Clark's Contribution to the Genesis of the Multiplier Analysis (With Some Unpublished Correspondence)." History of Economic Ideas 9 (1): 7-37.

Friedman, Milton. 1945. Incomes from Independent Professional Practice (with Simon Kuznets). New York: NBER.

Friedman, Milton. 1957. A Theory of the Consumption Function. Princeton NJ: Princeton University Press. Galbraith, John Kenneth. 1952. A Theory of Price Control. Cambridge, MA: Harvard University Press.

Gruchy, Allan. 1950. "Keynes and the Institutionalists: Some Similarities," and "Keynes and the Institutionalists: Important Contrasts." In C. Lawrence Christensen, ed., Economic Theory in Review. Bloomington: Indiana University Press, pp. 96-126.

Hansen, Alvin. 1947. "Two Interpretations of Keynesian Economics: Dr. Burns on Keynesian Economics." Review of Economics and Statistics 29 (November): 247-52.

Hawley, Ellis W. 1966. The New Deal and the Problem of Monopoly. Princeton NJ: Princeton University Press.

Hodgson, Geoffrey M. 2004. The Evolution of Institutional Economics. London: Routledge.

Keynes, John M. 1936. The General Theory of Employment, Interest and Money. London: Macmillan.

Keynes, John M. 1941. "Letter to J. M. Clark." In Donald Moggridge, ed., The Collected Writings of John Maynard Keynes, Vol. XXIII. London: Macmillan, pp. 192-93.

Keyserling, Leon H. 1972. "The Keynesian Revolution and its Pioneers-Discussion." American Economic Review 62 (1/2): 134-38.

Knapp, Joseph G. 1979. Edwin G. Nourse: Economist for the People. Danville: Interstate Printers and Publishers.

Koopmans, Tjalling C. 1947. "Measurement without Theory." Review of Economic Statistics 29 (August): 161-72.

Kuznets, Simon. 1936. "Review of The Formation of Capital by Harold G. Moulton and Income and Economic Progress by Harold G. Moulton.” Political Science Quarterly 51 (June): 300-306. 
Kuznets, Simon. 1942. Uses of National Income in Peace and War. New York: NBER.

Laidler, David. 1999. Fabricating the Keynesian Revolution: Studies of the Inter-war Literature on Money, the Cycle, and Unemployment. Cambridge: Cambridge University Press.

Lee, Frederic S. 1990. "From Multi-Industry Planning to Keynesian Planning: Gardiner Means, the American Keynesians, and National Economic Planning at the National Resources Committee." Journal of Policy History 2 (2): 186-212.

Lee, Frederic S. 1997. "Philanthropic Foundations and the Rehabilitation of Big Business, 1934-1977: A Case Study of Directed Economic Research." Research in the History of Economic Thought and Methodology 15: 51-90.

Lee, Frederic S. and Warren J. Samuels, eds. 1992. The Heterodox Economics of Gardiner C. Means: A Collection. Armonk, NY: M. E. Sharpe.

Leeson, Robert. 1997. "The Eclipse of the Goal of Zero Inflation.” History of Political Economy 29 (Fall): 445-96.

Leven, Maurice, Harold Moulton, and Clark Warburton. 1934. America's Capacity to Consume. Washington, DC: Brookings Institution.

Means, Gardiner C. 1935. "Industrial Prices and their Relative Inflexibility." Senate Document 13, 74th Congress, 1st Session. Washington, DC: US Govt. Printing Office.

Means, Gardiner C. 1939. The Structure of the American Economy: Part I, Basic Characteristics. Washington, DC: National Resources Committee.

Mehrling, Perry G. 1997. The Money Interest and the Public Interest. Cambridge, MA: Harvard University Press.

Mills, Frederick C. 1927. The Behavior of Prices. New York: NBER.

Mills, Frederick C. 1929. "Price Movements and Related Industrial Changes." In Recent Economic Changes, Report of the Committee on Recent Economic Changes of the President's Conference on Unemployment. New York: NBER.

Mills, Frederick C. 1936. Prices in Recession and Recovery. New York: NBER.

Mitchell, Wesley C. 1913. Business Cycles. Berkeley: University of California Press.

Mitchell, Wesley C. 1927. Business Cycles: The Problem and its Setting. New York: NBER.

Mitchell, Wesley C. 1969. Types of Economic Theory Vol. 2. New York: Kelley.

Moulton, Harold G. 1935a. The Formation of Capital. Washington, DC: Brookings Institution.

Moulton, Harold G. 1935b. Income and Economic Progress. Washington, DC: Brookings Institution.

Moulton, Harold G. 1943. The New Philosophy of Public Debt. Washington, DC: Brookings Institution.

Moulton, Harold G. 1949. Controlling Factors in Economic Development. Washington, DC: Brookings Institution.

Myrdal, Gunnar. 1972. Against the Stream: Critical Essays in Economics. New York: Pantheon Books.

Nourse, Edwin G. and Associates. 1934. America's Capacity to Produce. Washington, DC: Brookings Institution.

Nourse, Edwin G. 1944. Price Making in a Democracy. Washington, DC: Brookings Institution.

Report of the Columbia University Committee. 1934. Economic Reconstruction. New York: Columbia University Press.

Ross, Dorothy. 1991. The Origins of American Social Science. Cambridge: Cambridge University Press.

Rutherford, Malcolm. 1994. "J. A. Hobson and American Institutionalism: Underconsumption and Technological Change." In John Pheby, ed., J. A. Hobson After Fifty Years. London: Macmillan, pp. $188-210$.

Rutherford, Malcolm. 2002. "Morris A. Copeland: A Case Study in the History of Institutional Economics." Journal of the History of Economic Thought 24 (September): 261-90.

Rutherford, Malcolm. 2003a. "On The Economic Frontier: Walton Hamilton, Institutional Economics and Education." History of Political Economy 35 (Winter): 611-53.

Rutherford, Malcolm. 2003b. "American Institutionalism in the Interwar Period." In Warren Samuels, John Davis, and Jeff Biddle, eds., A Companion to the History of Economic Thought. Oxford: Blackwell, pp. 360-76. 
Rutherford, Malcolm. 2004. "Institutional Economics: The Term and its Meanings." Research in the History of Economic Thought and Methodology 22A: 179-84.

Rutherford, Malcolm. 2005a. "Who's Afraid of Arthur Burns?' The NBER and the Foundations." Journal of the History of Economic Thought 27 (June): 109-39.

Rutherford, Malcolm. 2005b. "Walton Hamilton and the Public Control of Business." In Steven G. Medema and Peter Boettke, eds., The Role of Government in the History of Economic Thought, Annual Supplement to Volume 37, History of Political Economy. Durham, NC: Duke University Press, pp. 234-73.

Shute, Laurence. 1997. John Maurice Clark. New York: St. Martin's Press.

Stapleford, Thomas A. 2006. "Market Visions: Liberal Reform and the Study of Consumption in the New Deal." Mimeo.

Slichter, Sumner H. 1934. "The Economics of Public Works." American Economic Review 24 (March): 174-85.

Slichter, Sumner H. 1937. "Safeguards Against Depression: An Analysis of Depression Cures." In Potentials of the American Economy: Selected Essays of Sumner H. Slichter. Cambridge, MA: Harvard University Press, 1961, pp. 72-82.

Slichter, Sumner H. 1961. Potentials of the American Economy: Selected Essays of Sumner H. Slichter. Cambridge, MA: Harvard University Press.

Tugwell, Rexford G. 1927. Industry's Coming of Age. New York: Harcourt, Brace.

Tugwell, Rexford G. 1931. "The Theory of Occupational Obsolescence." Political Science Quarterly 46 (June): 171-227.

Tugwell, Rexford G. 1932. "The Principle of Planning and the Institutional of Laissez Faire." American Economic Review 22 (March): 75-92.

Tugwell, Rexford G. 1935. "When Corporations Save." In The Battle for Democracy. New York: Columbia University Press, pp. 187-92.

Terborgh, George W. 1945. The Bogey of Economic Maturity. Chicago: Machinery and Allied Products Institute.

Veblen, Thorstein. 1904. The Theory of Business Enterprise. New York: Macmillan.

Veblen, Thorstein. 1921. The Engineers and the Price System. New York: Huebsch.

Vining, Routledge. 1939. "Suggestions of Keynes in the Writings of Veblen." Journal of Political Economy 47 (October): 692-704.

Wells, Wyatt C. 1994. Economist in an Uncertain World: Arthur F. Burns and the Federal Reserve, 1970-78. New York: Columbia University Press.

Witte, Edwin E. 1937. "Old Age Security in the Social Security Act." Journal of Political Economy 45 (February): 1-44.

Wright, David McCord. 1943. "Moulton's The New Philosophy of Public Debt." American Economic Review 33 (September): 573-90.

Wright, David McCord. 1945. "The Future of Keynesian Economics.” American Economic Review 35 (June): 284-307. 